\title{
Integrated Water Resources Management as a New Approach to Water Security
}

\author{
Olivier Graefe
}

\begin{abstract}
Access to safe water is a worldwide problem facing three quarters of a billion people every day. The problem of access to water is not primarily due to an overall scarcity of water, but rather the unequal geographical and seasonal distribution of the water resources. The key issue at stake here is, how to make water available. The new approach presented by international institutions for improving water access is Integrated Water Resource Management. This chapter questions this new approach and highlights the depoliticizing implications.
\end{abstract}

Keywords Access to water - Political ecology - Water scarcity • Water transfers • Water governance

Access to safe water is a worldwide problem facing three quarters of a billion people every day. In other words, one in ten people lack access to safe water according to the United Nations, a number which will increase in the future. By $2025,1.8$ billion people will be living in countries or regions with absolute water scarcity and two-thirds of the world population could live in regions under water stress conditions (UN 2009, 2015). The problem of access to water is not primarily due to an overall scarcity of water, but rather the unequal geographical and seasonal distribution of the water resources. The key issue at stake here is, how to make water available. Techniques to divert water to places where there is little or none or to store water for times of shortages have been developed since antiquity. The Roman aqueducts and the Ma'rib Dam in the ancient Kingdom of Saba' (8th century BC) are impressive examples of human ingenuity and engineering in order to overcome hydrological conditions. However, the issue today is not only of a technical or an ecological nature. Access to water for all is a question of investment, a question of financial means and thus the capacity of the different national, regional or local authorities to mobilize the means necessary to overcome the geographical

\footnotetext{
O. Graefe $(\square)$

Department of Geosciences, University of Fribourg, 4, Chemin Du Musée,

1700 Fribourg, Switzerland

e-mail: olivier.graefe@unifr.ch

(C) The Author(s) 2016

P. Jackson et al. (eds.), Eating, Drinking: Surviving,

SpringerBriefs in Global Understanding, DOI 10.1007/978-3-319-42468-2_5
} 
and seasonal disparities of water availability. It is thus a question of political will and of power relationships between stakeholders, the state and the people; essentially a question of the politics of controlling water sources like rivers and aquifers.

\section{Water Availability Is not an Ecological Issue, but a Management Problem Solved at High Social and Ecological Costs}

That water availability is not dependent on ecological conditions is particularly obvious in regions such as Africa, Central Asia, the USA, as well as in China. Neighboring countries with similar ecological conditions in North- as well as in West Africa have very different access rates to safe water sources. In the Democratic Republic of Congo only three quarter of the population is provided with safe drinking water, despite holding nearly a quarter of all renewable water resources and represents the water richest country of the entire continent. In contrast, in very dry countries like Egypt or Namibia, nearly $100 \%$ of the population has access to safe drinking water (MDG 2015). The problems of water supply are obviously not of an ecological nature but are the outcome of the political economy specific to these countries. The importance of the political economy to understand water availability is also evident in the American West, where the water supply for drinking water, irrigation, and the industry of not only California, but also of the western states like Nevada, Arizona, and Utah has been developed in a particular socio-economic and political context presented in famous books like "Rivers of Empire" by D. Worster (1985) and "Cadillac Desert" by M. Reisner (1986). Other famous examples of how limited hydrological conditions are overcome on a large scale in order to enable urban, agricultural, and industrial development can be seen in the control and exploitation of the Amou-Daria and the Syr-Daria in Central Asia or the Yangtse in China. Rivers here have been tamed, controlled, and managed in order to exploit them in the service of the economy, the people and the state. But the control and the exploitation, (i.e. the management patterns of these rivers) have created social and economic inequalities, sometimes even dramatic ecological consequences. Of major concern is the removal of people and the loss of properties due to the construction of dams. According to the World Commission on Dams, between 40 and 80 million people have been displaced worldwide since the 1940s often without recovering their livelihoods (World Commission on Dams 2000). The displacement of people, as well as the consequences downstream leads to an increase of social and economic disparities. Very few people (mostly the national elites) actually benefit from these dams and the economic wealth created by it, while the majority of people loose their livelihoods, triggering oppositions and sometime virulent resistance. Another issue created by the construction of dams is the unequal water share riparian states can use, despite treaties, and agreements. Successive treaties over the use of Nile water between Egypt, Ethiopia, and Sudan 
f.e. have resulted in inequitable rights in favor of Egypt and thus to recurring tensions between these neighboring countries (Tafesse 2001). Finally, the approach of making more water available for drinking, irrigation, and industry has lead to significant ecological disasters. The depletion of water resources f.e. has significantly shrunk the Tchad Lake and the Aral sea and thus led to the salinization and the sterilization of vast areas that surround the sea. Furthermore, rivers do not carry sufficient water downstream of dams leading to the disappearance of aquatic and non-aquatic species. While new initiatives like the EU Water Framework Directive do try to reduce the ecological impacts, many damages are still to be addressed.

Because of the resistance and tensions at various scales, international institutions advocated a new water management approach in order to better integrate various national, regional, local stakeholders, as well as users from the agricultural, industrial, and drinking water sectors. The division and competition between these sectors led to conflicts and to the depletion of the resources as the water supply has been raised to solve or anticipate the conflicts between users.

The new approach thus is the "Integrated Water Resource Management", which is closely linked to the river basin as the privileged territorial management unit.

\section{IWRM: The New Water Management Paradigm}

The choice of the river basin as the geographical reference for the Integrated Water Resource Management (IWRM) has been promoted by the most prominent institutions involved in the water sector [f.e. Global Water Partnership (2010); UNESCO (2009); UN (2009); World Water Council (2015), etc.]. The EU in particular, has taken this scale as the new reference unit for the Water Framework Directive, which all EU member states implement. As such, it was praised in 2002 at the Earth summit Rio +10 conference in Johannesburg. Since then, the relevance of the river basin has been promoted repeatedly in strategy papers, reports, and policies. River basins across national borders are subject of an increasing number of international river treaties or management organizations. Famous examples include the Danube River Protection Convention signed in 1994, the Mekong River Commission created in 1995 and the Nile Basin Initiative created in 1999. In total 167 international cooperation conventions or treaties for river basins are in place today (Blanchon 2009). In particular, the Global Water Partnership is a strong advocate of the basin approach as management unit and brings forward the key argument for the river basin as reference scale: "Water flows according to natural characteristics and does not respect administrative boundaries-therefore the question arises: should water be managed and management structures be defined according to existing administrative boundaries or according to natural boundaries, usually taken to be river basins? From a pure water resource point of view might there be a logic to adopting a river basin approach, or at least considering the river basin as the logical planning unit" (Global Water Partnership 2010: 47). This rhetorical question tries to establish the choice of the water divide as a boundary, 
because it is given by nature and therefore most relevant for ecological sound management (Blomquist and Schlager 2005). Nevertheless, this choice ignores that the choice itself is neither natural, nor self-evident. The high complexity of today's water management practices and the multiple connections of river basins through water transfers make this territorial management unit as geographical reference only partially appropriate.

\section{Water Management Practices: Plumbing and Pumping}

The emphasis on the river basins neglects the widespread practice of water transfers, even though these practices are well known since the beginning of irrigation techniques. The construction of dams allows the transfers of extensive water quantities in the Americas, but also in Asia and Africa. The most prominent example at a large scale in Africa is the Lesotho Highlands Water project in South Africa. Another example is the transfer of water from the Kunene River into the Cuvelai basin thanks to the Calueque dam for the supply of North Namibia. Today, 120 million people worldwide depend on water transfers for their water consumption. It is estimated that $1000 \mathrm{~km}^{3}$ of water will be transferred between basins every year for the next 20 years, especially after the completion of projects in India and China like the South-North Water Transfer Project diverting water from the Yangtse thanks to the Three Gorges Dam to the Yellow river basin (Blanchon 2009; Niemann 2008; Kluge 2005). The connectivity of rivers, water transfers, and diversions are well established and contradict the dominant conception of IWRM and the correlated scale of the river basin.

\section{Water Governance as the New Panacea}

The river basin is seen as a possibility to overcome or circumvent existing administrative and political boundaries (Molle 2009). Using the river basin as the territorial management unit is an attempt to impose a new and "natural" territory, which is justified and legitimized by (natural) sciences. It is an attempt to enforce a new scale for the water management and hence to bypass existing political and administrative instances and the related power relationships. The global actors like the Global Water Partnership, UNDP, the World Bank, and the EU try to convey in this way the political question of resource management in a managerial and technocratic frame of governance (Moss 2003). Water governance can be understood in the framework of the debate around the meaning of governance. For several critical authors, the concept of governance serves as a substitute for concepts of government through the reduction of social and political features in the processes of decision-making. Governance hence, refers to mechanisms and to coordinated activities directed towards problem solving. By contrast for government and non government governance is an attempt to minimize the political, e.g., debates, 
conflicts and politically binding and transparent decision-making processes, to replace them by a defined policy, i.e. guidelines, (bench markings, best practices etc.) and parallel instances. The beneficiaries of management decisions according to critics are not individual people any more seen as collective political subjects, but rather the population as a mass, which are the victim of external environmental problems. This depolitization reduces decisions concerning resource allocation to policy definitions and a consensus oriented and procedural management beyond democratic representative instances (Swyngedouw 2010). From this perspective, water governance and the correlated IWRM approach resemble a take-over of the public water management by environmental experts without political and democratic legitimization (Graefe 2013).

The exclusive choice of the river basin as territorial management unit is questioned in light of the increasing importance of water transfers. To privilege one specific scale in order to control the growing interconnectivity of basins and the overall complexity of water management seems not only naive and wrong, but is also misleading to find appropriate solutions to gain water security. The problems are neither of technical nor hydrological nature but are above all political.

The challenge of access to water for drinking, irrigation, and industry all depends on the political choices of national and international authorities. Investments are necessary in order to apply existing technologies and more efficient management strategies reducing the water demand and consumption. It is estimated that 100 billion dollars per year would suffice to secure water access to all, including the poor in the Global South (Blanchon 2009). It is finally a question of national and international understanding and solidarity, which will secure the fundamental right to safe drinking water.

\section{References}

Blanchon, D. (2009). Atlas mondial de l'eau. De l'eau pour tous? Autrement, Paris.

Blomquist, W., \& Schlager, E. (2005). Political pitfalls of integrated watershed management. Society \& Natural Resources, 18(2), 101-117.

Global Water Partnership. (2010). Integrated Water Resources Management (http://www.gwp.org/ en/The-Challenge/What-is-IWRM/Dublin-Rio-Principles/. Access 7 January 2011).

Graefe, O. (2013). The river basin as territorial water management unit. Towards post-political water management. In G. Arnaud-Fassetta, E. Masson \& E. Reynard (Eds.), European continental hydrosystems under changing water policy (pp. 11-16). München: Friedrich Pfeil Verlag.

Kluge, T. (2005). Kritische Betrachtung des Ansatzes "Integriertes WasserressourcenManagement” (IWRM). In S. Neubert, W. Scheumann, A. van Edig \& W. Huppert (Eds.), Integriertes Wasserressourcen-Management (IWRM). Ein Konzept in die Praxis. Deutsches Institut für Entwicklungspolitik (pp. 31-43). Baden-Baden: Nomos.

Molle, F. (2009). River-basin planning and management: The social life of a concept. Geoforum, 40(3), 484-494.

Moss, T. (2003). Solving problems of 'fit' at the expense of problems of 'interplay'? The spatial reorganisation of water management following the EU Water Framework Directive. In $\mathrm{H}$. 
Briet, E. Engles, T. Moss, \& M. Troja (Eds.), How institutions change: Perspective on social learning in global and local environmental concerns (pp. 85-121). Opladen: Leske + Budrich.

Niemann, S., 2008. Spatial aspects of supply: Migration, water transfer and IWRM. In: D. Hummel (Ed.), Population dynamics and supply systems. A transdisciplinary approach (pp. 99-128). Frankfurt a.M.

Reisner, M. (1986). Cadillac desert: The American west and its disappearing water. New York: Viking Penguin.

Swyngedouw, E. (2010). Apocalypse Forever?: Post-political Populism and the spectre of climate change. Theory, Culture \& Society, 27, 213-232.

Tafesse, T. (2001). The nile question: Hydropolitics, legal wrangling. Modus Vivendi and Perspectives: London, Transaction Publishers.

UNESCO. (2009). IWRM guidelines at River Basin level, part 1. Principles. Paris: Unesco Publishing.

United Nations. (2009). United Nations World Water Development Report 3. Water in a changing world. Earthscan, Paris: Unesco Publishing.

United Nations. (2015). Millennium Development Goals Report 2015, New York.

World Commission on Dams (2000). Dams and development. A new framework for decision-making. London and Sterling, Earthscan Publications.

World Water Council. (2015). Integrated Water Resource Management: A new way forward. A Discussion Paper of the World Water Council Task Force on IWRM. http://iucn.org. Access 11 May 2016.

Worster, D. (1985). Rivers of empire. Water, aridity, and the growth of the American West. Oxford: Oxford University Press.

Open Access This chapter is distributed under the terms of the Creative Commons Attribution 4.0 International License (http://creativecommons.org/licenses/by/4.0/), which permits use, duplication, adaptation, distribution and reproduction in any medium or format, as long as you give appropriate credit to the original author(s) and the source, provide a link to the Creative Commons license and any changes made are indicated.

The images or other third party material in this chapter are included in the work's Creative Commons license, unless indicated otherwise in the credit line; if such material is not included in the work's Creative Commons license and the respective action is not permitted by statutory regulation, users will need to obtain permission from the license holder to duplicate, adapt or reproduce the material. 


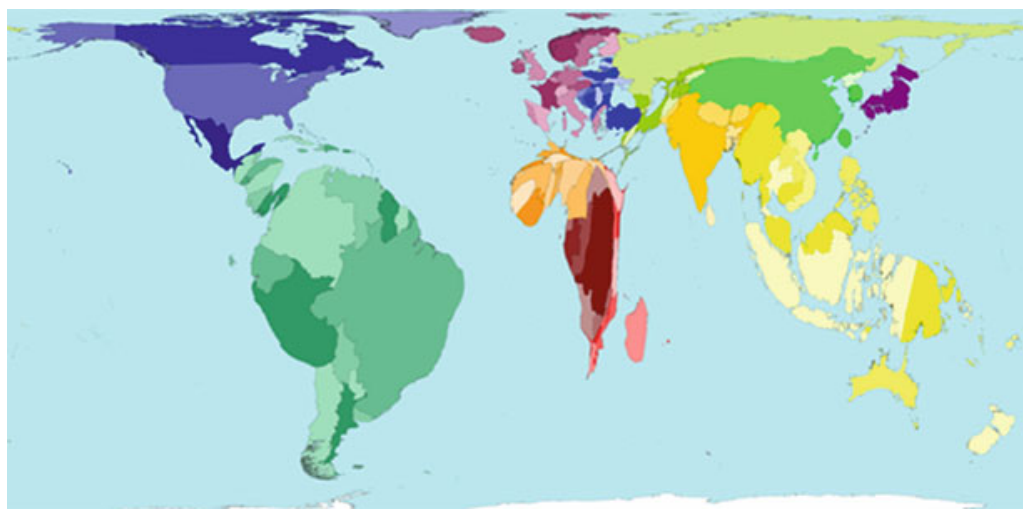

Water resources. Water resources here include only freshwater, because saline (sea) water requires treatment before most uses. Territory size shows the proportion of all worldwide freshwater resources found there. Source www.worldmapper.org. Published with kind permission of (C) Copyright Benjamin D. Hennig (Worldmapper Project)

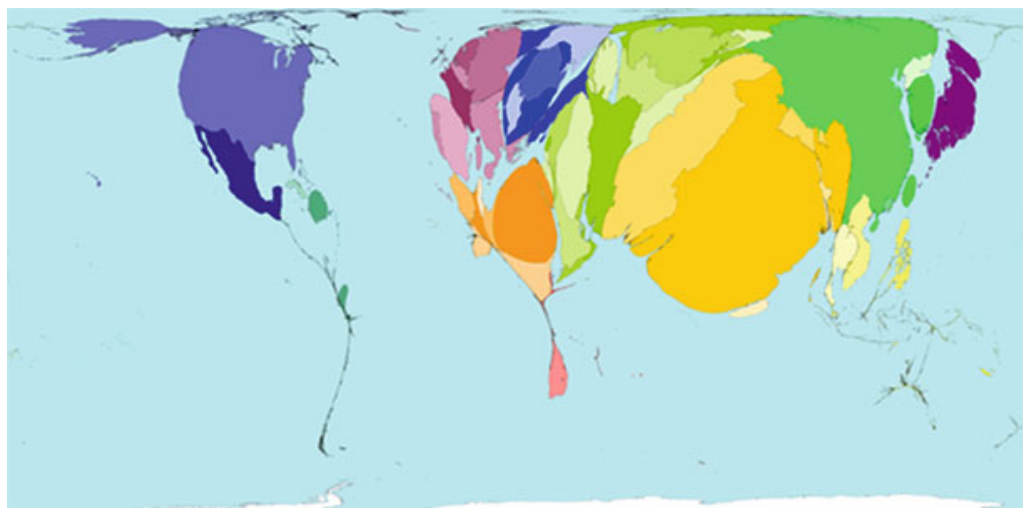

Water depletion. This map shows those territories that use much of their internal water resources, measured with a threshold of people using more than $10 \%$ of renewable water resources. Each territory is resized based on the volume of water used beyond $10 \%$. Territory size shows the proportion of all water used that is more than $10 \%$ of the renewable internal freshwater resources of that territory. Source www.worldmapper.org. Published with kind permission of (C) Copyright Benjamin D. Hennig (Worldmapper Project) 